\title{
Socio-Cultural Barriers to Voluntary Blood Dona- tion for Obstetric Use in a Rural Nigerian Village
}

\author{
OUJ Umeora', SO Onub ${ }^{2}$ and MC Umeora ${ }^{3}$
}

\begin{abstract}
Availability of blood for transfusion is of utmost importance in the fight against maternal morbidity and mortality. This study was conducted to identify the socio-demographic characteristics and reasons of persons declining voluntary blood donation. Patients' relatives declining blood donation in rural Ebonyi State were randomly recruited and interviewed using standardised questionnaire after obtaining informed consent from each of them. Responses were ranked according to frequency of positive respondents. Illiteracy was prevalent among the population: over $76 \%$ had no formal education. 'Not being strong enough' and 'not having enough blood' were the two major reasons for declining blood donation, while loss of manhood/libido and exposure of blood to witchcraft were the other reasons given. Respondents' level of awareness of HIV/AIDS was appreciable. Socio-cultural barriers to voluntary blood donation exist in predominantly illiterate rural communities of the country. Most of the reasons given were based on misconception, misinformation and ignorance about the effect and safety of blood donation. (Afr J Reprod Health 2005; 9[3]:72-76)
\end{abstract}

\section{RÉSUMÉ}

Obstacles socio-culturels au don volontaire du sang destiné à l'usage obstétrical dans un village Nigérian rural La disponibilité du sang destiné à la transfusion est d'une importance capitale dans le combat contre la morbidité et la mortalité maternelles. Cette étude a été menée afin d'identifier les caractéristiques socio-démographiques et les raisons pour lesquelles les gens ne veulent pas faire le don volontaire du sang. Les parents des patients qui ne veulent pas faire le don volontaire du sang dans l'état d'Ebonyi rural ont été recrutés et interviewés au hasard à l'aide d'un questionnaire standardisé, suite à l'obtentionn du consentement éclairé de chacun d'eux. Nous avons classifié les réponses selon la fréquence des repondants positifs. L'analphabétisme était prévalent auprès de la population; plus de 76\% n'avaient pas reçu une instruction formelle. Les deux principales raisons pour lesquelles ils ne donnaient pas du sang étaient "n'est pas assez en bonne santé" et" on n'a pas assez de sang", alors que la perte de sa virilité, ainsi que le fait d'exposer le sang à la sorcellerie étaient les deux autres raisons avancées. Le niveau de la conscience du VIH/SIDA était considérable. Les obstacles socio-culturels au don volontaire de sang existent dans les communautés essentiellement illetrées et rurales du pays. La plupart des raisons données ont été fondées sur des opinions fausses, des désinformations et l'ignorance au sujet de l'effet et de la sécurité du don de sang. (Rev Afr Santé Reprod 2005; 9[3]:72-76)

KEY WorDs: Culture, blood, donation, transfusion, HIV/AIDS, Ebonyi

${ }^{1}$ Department of Obstetrics \& Gynaecology, Ebonyi State University Teacbing Hospital, Abakaliki. Ebonyi State, Nigeria. ${ }^{2}$ Department of Obstetrics \& Gynaecology, Nisa Premier Hospital, Alex Ekwneme Way, Jabi, Abuja, Nigeria. ${ }^{3}$ Department of Paediatrics, Ebonyi State University Teaching Hospital, Abakaliki, Ebonyi State, Nigeria.

Correspondence: DrOUJ Umeora, P. O. Box 980, Abakaliki 480001, Ebonyi State, Nigeria. E-mail:oujain@yahoo.com; Tel: 2348039558074

\section{Introduction}

Globally, an estimated 600,000 women die annually during childbirth, majority of who are in sub- 
Saharan Africa. ${ }^{1}$ In Nigeria the average maternal mortality ratio (MMR) is 1,000 per 100,000 maternities. ${ }^{2}$ Obstetric haemorrhage accounts largely for these mortalities. Massive blood loss results rapidly in mortality if prompt and adequate life-saving measures, including blood transfusion, are not taken on time. ${ }^{1}$

Blood for transfusion is not readily available in Nigeria. ${ }^{3}$ The wastage implicit in the inability to separate available blood into various useful components further compounds the scarcity. Most blood bank operators in the country are also known to rely on touts for their supply. ${ }^{4}$ With the high prevalence of HIV in Nigeria $(5.4 \%)^{2}$ and the increasing number of HIV positive blood donors, the obstetric patient in need of blood transfusion faces a precarious situation.

More often, blood bank operators turn to patients' relatives for blood donation during emergencies. Studies from some parts of Africa have revealed attitudinal barriers to such donations. ${ }^{5}$ Few studies on the subject have been undertaken in Nigeria. This study, therefore, aimed at identifying the socio-cultural barriers to blood transfusion in a rural village in south-east Nigeria.

\section{Methods}

This study was conducted at St Vincent's Catholic Hospital, Ndubia, an agrarian community in rural Ebonyi State of Nigeria, over a 12-month period (September 1, 2003 to August 31, 2004). The hospital serves both as a primary contact with orthodox medicine and a referral centre for the community and surrounding towns in Ebonyi and neighbouring Cross River State. Staffed with medical officers and a resident consultant obstetrician and gynaecologist, the hospital attends to numerous obstetric and gynaecological cases including those requiring blood transfusion. Patients' relations and friends are often called upon for blood donation whenever the need arises. Blood from donors are screened for infectious diseases including HIV/AIDS before transfusion.

African Journal of Reproductive Health Vol. 9 No.3 December 2005
Patients' relations and friends who declined blood donation were randomly recruited into the study. Informed consent was obtained in each case before subsequent interview by the investigators. Pre-tested questionnaire was administered to the respondents in Igbo or English language to ensure adequate understanding. Reasons given by the respondents were ranked according to frequency of response.

\section{Findings}

A total of 143 respondents were recruited into the study, out of which $118(82.5 \%)$ were males and the remaining $(17.5 \%)$ females. Seventy-two $(50.3 \%)$ of them were aged between 25 and 34 years, an overwhelming majority $109(76.2 \%)$ had no formal education. None of the respondents had post-secondary education. Majority $(71.3 \%)$ of the respondents were farmers and petty traders, while $80.4 \%$ of them were Christians. Jehovah's Witnesses were excluded from the study because of their religious aversion to blood donation and transfusion.

The two commonest reasons for not donating blood (Table 2) were 'not feeling well/ strong enough' (63.6\%) and 'not having enough blood' (58\%). Seventy-eight respondents (54.5\%) believed that they would collapse if they donated blood, while 46 (32.1\%) of them felt that it could shorten their lifespan. Other reasons included for not wanting to donate blood included loss of 'manhood' (libido) (27.1\% of the men), increased risk of illness/infection (35.7\%) and possibility of blood being exposed to rituals/witchcraft $(28.7 \%)$. Sixteen respondents $(11.2 \%)$ had no particular reason for refusing to donate blood.

Level of awareness about HIV/AIDS was appreciable among the respondents but none of them was aware of his/her HIV status. Twentyfour of the respondents $(16.8 \%)$ feared that their HIV status might be positive and could be exposed because of lack of confidentiality by the medical personnel. Almost 19\% of the respondents believed that cases requiring blood transfusion are 
74 African Journal of Reproductive Health

already beyond medical remedy. Fifteen of the respondents $(34.9 \%)$ said that they would consider donating blood if the patient were their relative. Only two $(1.4 \%)$ respondents said that their traditional norms was against blood donation, while four $(2.8 \%)$ of them said that they were

\section{Table 1 Socio-Demographic Characteristics of Respondents}

\begin{tabular}{lrr}
\hline Characteristic & Number & Percentage \\
\hline Age (years) & 3 & 2.1 \\
$\leq 19$ & 15 & 10.5 \\
$20-24$ & 29 & 20.3 \\
$25-29$ & 43 & 30.1 \\
$30-34$ & 27 & 18.9 \\
$35-39$ & 15 & 10.5 \\
$40-44$ & 11 & 7.7 \\
$\geq 45$ & & 76.2 \\
Educational status & 109 & 21.7 \\
No formal education & 31 & 2.1 \\
Primary & 3 & 0 \\
Secondary & 0 & 41.9 \\
Tertiary & & 9.8 \\
Occupation & 60 & 9.1 \\
Farming & 14 & 9.8 \\
Tailor/seamstress & 13 & 29.4 \\
Artisan & 14 & 80.4 \\
Civil servant & 42 & 19.6 \\
Trading & & \\
Religion & 115 & 28 \\
Christianity & 28 & \\
African Traditional Religion & & \\
\hline
\end{tabular}

Table 2 Reasons for Declining Blood Donation

\begin{tabular}{lcc}
\hline Reason & Number & $\mathbf{\%}$ \\
\hline 'Yes' response to questions & & 63.6 \\
Not well/not strong enough & 91 & 58.0 \\
Not having enough blood & 83 & 54.5 \\
Fear of collapse & 78 & 35.7 \\
Increased risk of illness/infection & 51 & 28.7 \\
Exposure of blood to witchcraft & 41 & 30.1 \\
Not related to patient & 43 & 22.4 \\
Loss of manhood (libido) & 32 & 18.9 \\
Not medically helpful & 27 & 16.8 \\
Fear of being HIV positive & 24 & 32.2 \\
Reduces life span & 46 & 11.2 \\
No particular reason & 16 & 2.8 \\
Fasting & 4 & 1.4 \\
Against traditional norm & 2 & 49.7 \\
Would donate for financial gain & 71 & \\
\hline
\end{tabular}


Despite the general trend towards a reduction in blood transfusion in obstetric and gynaecological practice for reasons of HIV transmission and cost, there still exist conditions that of necessity require transfusion, ${ }^{6}$ it is, therefore, of utmost importance that blood is readily available in such instances.

Worldwide, haemorrhage accounts for about $25 \%$ of maternal deaths. ${ }^{7}$ In Nigeria, a ten-year analysis of maternal mortality across the six geopolitical zones showed that haemorrhage accounted for $21 \%$ of deaths if the general diagnosis was just 'haemorrhage', rising to $32.9 \%$ if ectopic gestation and ruptured uterus were included. ${ }^{2}$ One of the millennium development goals is the reduction in maternal mortality as an important step towards improving maternal health globally. ${ }^{8}$ Effective blood banking services play crucial role in intervention strategies aimed at reducing maternal mortality as a result of obstetric haemorrhage. Blood for transfusion is not readily available, and some regions of the world like South-East Asia face severe shortage of safe blood.' Some illegal blood banks source blood from touts, and this has made blood transfusion the second largest source of HIV infection in Nigeria after unsafe sex. ${ }^{4}$ The use of adequately screened volunteers would go a long way in making available safe units of blood for transfusion. Unfortunately, these volunteers are not readily available, as blood donation in Africa is seen to represent extreme sacrifice. ${ }^{10}$

The literacy level of respondents in this study was very low (Table 1), farming and petty trading being the predominant occupations. The poor educational status might have grossly affected their perception of blood transfusion. An earlier study in Tanzania ${ }^{5}$ showed that voluntary blood donation was correlated to secondary school attendance. In our series only $2.1 \%$ of the subjects had post-primary education. The health behaviour and health-seeking practices of a population is grossly affected by personal, communal and societal beliefs and norms, as well as their perception of health and disease. ${ }^{2}$ The perception of the respondents' state of health was the most common reason for declining blood donation. While some believed that they were not strong enough, would collapse, or did not have enough blood, others reasoned that they could be infected ( $\mathrm{Ta}$ ble 2). The superstitious beliefs and myths prevalent in these communities were evident by the reasons of exposure of blood to witchcraft, loss of manhood and reduction in lifespan (Table 2).

Only a few of the respondents said that it was against their traditional values. However, about half of the respondents would donate blood for some form of financial gain. This may provide a leeway for most blood bank operators through encouraging patients' relatives with some form of material or health reward. This revelation was also evident in the Tanzanian study. ${ }^{5}$ The fear of discovering that one is HIV positive was another reason for some respondents' negative attitude to blood donation. Such fear is common in Africa. ${ }^{5,10}$ Voluntary HIV/AIDS counselling and testing is highly recommended before recruiting donors who are afraid they could be HIV positive, while ways of reducing blood transfusion in obstetrics and gynaecology should be sought. A group and screening policy should be acceptable for most procedures. ${ }^{6}$ Autologous transfusion should also be encouraged. Instituting a multidisciplinary committee on blood transfusion would enhance proper monitoring, evaluation and control of blood utilization in the hospital. ${ }^{6,11}$

\section{Conclusion}

Some socio-cultural barriers to voluntary blood donation exist in predominantly illiterate rural communities in Nigeria. Most of the reasons were based on misconception, misinformation and ignorance about the effect and safety of blood donation. Massive public health and literacy campaigns are advocated to inform and educate the rural populace. This will allay their un- 
76 African Journal of Reproductive Health

founded but real fears and dispel some unreasonable but deep-rooted beliefs. Voluntary rather than commercial blood donation should be encouraged to ensure steady supply and availability of safe blood for transfusion in hospitals. Some derivable interests in terms of financial remuneration, knowledge of HIV status and blood group should also accrue to blood donors as inducement.

\section{Acknowledgement}

The authors are grateful to Mr. Dom Fot, the laboratory scientist, for his immense contribution to this study.

\section{REFERENCES}

1. World Health Organization. Reduction of Maternal Mortality. A Joint WHO/UNFPA/ UNICEF/World Bank Statement. Geneva: WHO, 1990; 10-13.

2. Federal Ministry of Health. Maternal Mortality Situation and Determinants in Nigeria. A Review Commissioned by the Federal Ministry of Health, Abuja, 2004; 1.

3. Anorlu RL, Orakwe CO, Abudu OO and Akanmu AS. Uses and misuse of blood transfusion in Obstetrics in Lagos, Nigeria. W Afr J Med 2003; 22(2): 124-127.

4. Raufu A Risinf. HIV infection through blood transfusion worries Nigerian health experts. AIDS Analysis Afr 2000; 11(1): 15.

5. Jacobs B and Berege ZA. Attitudes and beliefs about blood donation among adults in Mwanza region, Tanzania. E Afr Med J 1995; 72(6): 345-348.

6. Royal College of Obstetrics and Gynaecology. Blood transfusion in obstetrics a $\mathrm{n} \mathrm{d}$ gynaecology. Br J Obstet Gynaecol 1997; 104: 278-284.

7. World Health Organization. Mother-Baby Package: Implementing Safe Motherhood in Countries. Practical Guide. Geneva: WHO Maternal Health and Safe Motherhood Programme, 1994; 1-7.

8. United Nations. Millennium Declaration, New York 2000. htpp:/www.un.org/millennium/are5552e.pdf.

9. Sharma R. South East Asia faces severe shortage of safe blood. BMJ 2000; 320(7241): 1026.

10. Gobatto I. Donating blood in the time of AIDS. Some ideas from a study in Bangui. Soc d'Afr Sida 1996; 13: 8-10.

11. King DJ. Transfusion and the use of blood products. Baill Clin Haematol 1991; 4: 545569. 